\title{
Actinomycosis of the head in a 13 year old girl
}

\author{
*Abhijit Anil Patil ${ }^{1}$, P S Chandrasekar ${ }^{1}$ \\ Sri Lanka Journal of Child Health, 2018; 47(2): 172-173 \\ DOI: http://dx.doi.org/10.4038/sljch.v47i2.8487 \\ (Keywords: Actinomycosis, Benzyl penicillin)
}

\section{Case report}

A 13 year old girl presented with several swellings in the right side of the scalp of 2 months duration which were fluctuant and non-tender.

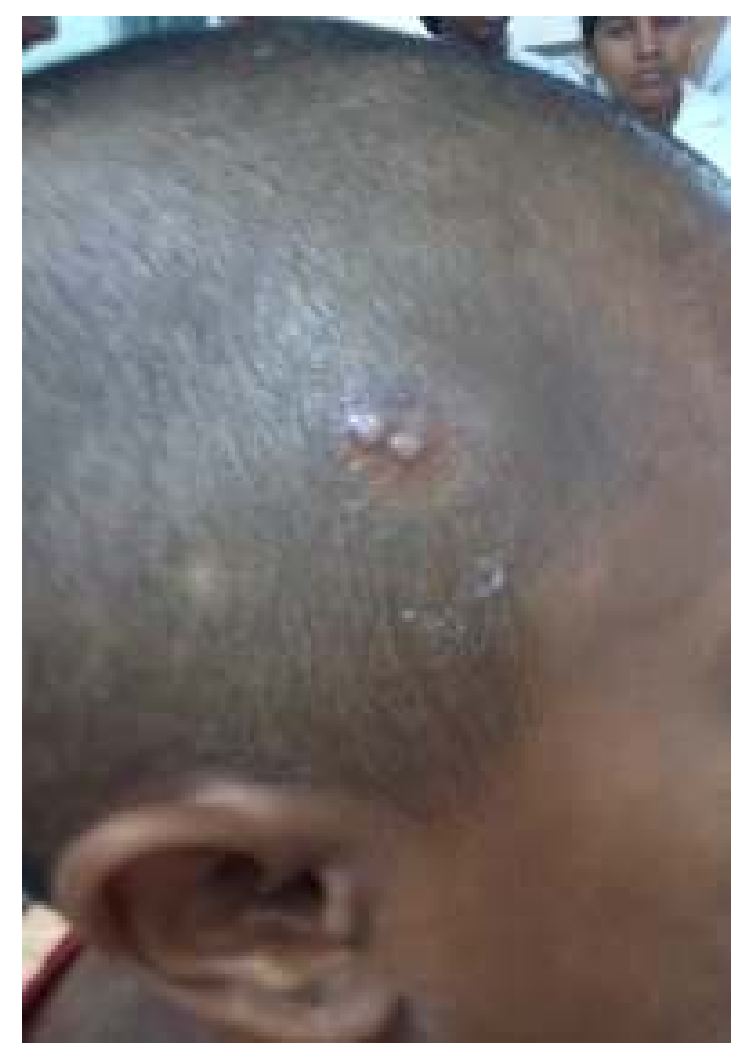

Figure 1: Swellings in right side of scalp

There was no history of pain or tenderness over the swellings, no history of trauma or pricks to the head and no history of fever, headache, cough, vomiting or involuntary movements. She had received multiple courses of antibiotics for this complaint over the last 2 months without any improvement. There was no history of contact with tuberculosis.

\section{${ }^{1}$ Kovai Medical Centre and Hospital, India \\ *Correspondence:abhi_neurology@rediffmail.com}

(Received on 15 November 2016: Accepted after revision on 23 December 2016)

The authors declare that there are no conflicts of interest

Personal funding was used for the project.

Open Access Article published under the Creative

Commons Attribution CC-BY Cc

She was thin and malnourished. Her systemic examination was normal. Oral examination revealed normal healthy teeth. Her tonsils were not ulcerated or inflamed. Her haemoglobin was $9.6 \mathrm{~g} / \mathrm{dl}$ and the peripheral blood film showed microcytic hypochromic anaemia. The white blood cell count was 8000 per cu mm (neutrophils $44 \%$, lymphocytes $50 \%$, monocytes $2 \%$ and eosinophils $4 \%$ ). The platelet count was 170,000 per cu mm. Human immunodeficiency virus (HIV) serology was negative. No other investigations were done to exclude an immunodeficiency which thus remains a possibility. Chest x-ray was normal. The Mantoux test was negative. Histopathology of the excised specimen showed skin with fistula lined by inflammatory granulation tissue consisting of mixed inflammatory infiltrates; focally a haematoxyphilic collection of actinomyces filaments was seen. Computed tomography (CT) scan showed sclerotic thickening with cortical irregularity and lytic areas involving the right temporal, right parietal and occipital bones, suggestive of osteomyelitis and scalp thickening with multiple loculated collections adjacent to thickened bone suggestive of abscesses (Figure 2).

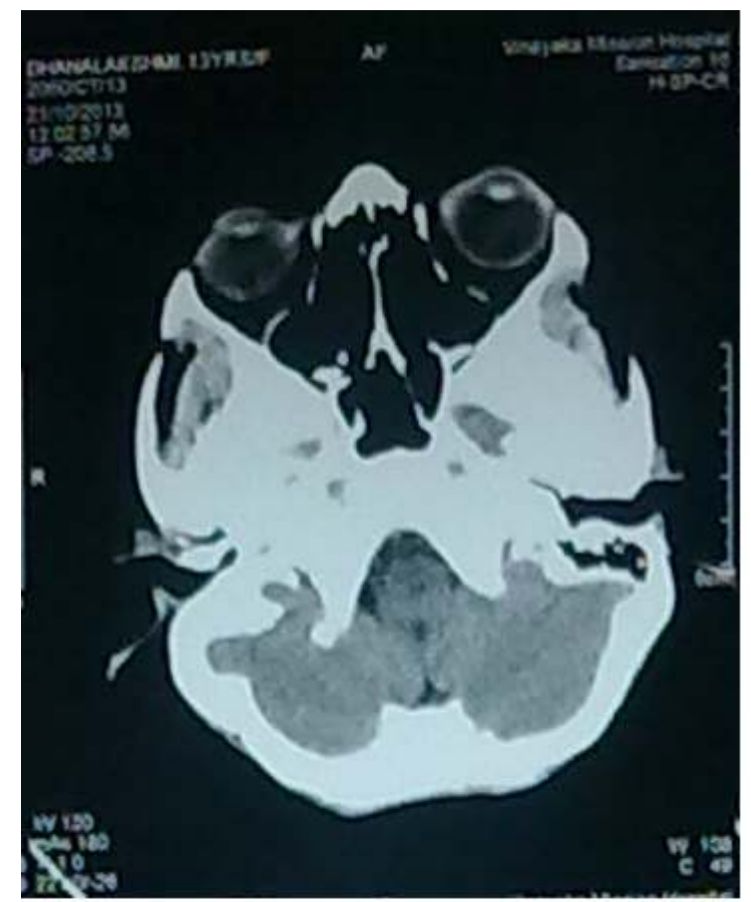

Figure 2: CT scan showing sclerotic thickening with cortical irregularity and lytic areas involving right temporal, right parietal and occipital bones 
She was treated with intravenous benzyl penicillin for 6 weeks and we are continuing with oral penicillin for six months. She responded well to treatment. Her lesions healed well. She is coming to the outpatients department for follow up.

\section{Discussion}

Actinomycosis is a chronic disease caused by anaerobic Gram-positive bacteria belonging to the Actinomyces species that normally colonize the human digestive and genital tracts ${ }^{1}$. The disease is characterized by abscess formation, tissue fibrosis, and draining sinuses ${ }^{2}$. Actinomycosis of the skull is very rare ${ }^{3}$. However, it has been previously reported in a 13 year old girl ${ }^{3}$. In our patient, CT scan showed osteomyelitis of right temporal, right parietal and occipital bones. Accurate diagnosis is based on bacterial cultures and histopathology but prolonged bacterial cultures in anaerobic conditions are necessary to identify the bacterium ${ }^{1}$. Typical microscopic findings include necrosis with yellowish sulphur granules and filamentous Grampositive fungal-like pathogens ${ }^{1}$. In our patient histopathology showed skin with fistula lined by inflammatory granulation tissue and focally a haematoxyphilic collection of actinomyces filaments. Optimal treatment includes a 6-12 month course of high dose Benzyl penicillin or amoxicillin $^{1}$. Our patient was treated with intravenous benzyl penicillin for 6 weeks and we are continuing with oral penicillin for 6 months.

\section{References}

1. Valour F, Sénéchal A, Dupieux C, Karsenty J, Lustig S, Breton P, et al. Actinomycosis: Aetiology, clinical features, diagnosis, treatment, and management. Infection and Drug Resistance 2014; 7: 183-97.

PMid: 25045274 PMCid: PMC4094581

2. Schaal KP, Lee HJ. Actinomycete infections in humans - a review. Gene 1992; 115(1-2):201-11. https://doi.org/10.1016/03781119(92)9056 $0-\mathrm{C}$

3. Vannier JP, Schaison G, George B, Casin I. Actinomycotic osteomyelitis of the skull and atlas with late dissemination. A case of transient neurosurgical syndrome. European Journal of Pediatrics 1986; 145(4): 316-8.

https://doi.org/10.1007/BF00439411

PMid: 3770003 